\title{
ORIGINALS
}

\section{Studies of the Cholinergic Receptors Involved in the Secretion of Insulin Using Isolated Perfused Rat Pancreas}

\author{
M. M. Loubatières-Mariani, J. Chapal, R. Alric and A. Loubatières \\ Laboratoire de Pharmacologie et de Pharmacodynamie, Faeulté de Médecine, Institut de Biologie, Montpellier, France \\ Received: January 3, 1973, and in revised form: June 18, 1973
}

\begin{abstract}
Summary. Studies of the role and nature of the cholinergic receptors acting on the secretion of isolated per. fused rat pancreas have shown the following: The infusion of acetylcholine at a dose of $2.5 \mu \mathrm{M}$ in the presence of a concentration of glucose of $1.5 \mathrm{~g} / 1$, provoked a first phase of immediate and important stimulation of the secretion of insulin; this initial peak of insulin secretion was followed by a second phase during which a new less intense stimulation occurred; the latter was followed by an inhibition appearing at a time that dopended on the pancreas used. At a dose of $0.5 \mu \mathrm{M}$ of acetylcholine, the first phase of stimulation always appeared; during the second phase some pancroases were inhibited, others remained stimulated. - The peak of insulin secretion obtained by stimulation with acetylcholine during the first phase was dose related. - Eserine intensified the
\end{abstract}

effects of acetylcholine. - The presence of glucose was essential for the insulinsecretory action of acetylcholine. The muscarinic nature of the cholinergic receptors implicated in the secretion of insulin was demonstrated by the use of: - Atropine which completely blocked the effects of acetylcholine, - Muscarine which produced the same effects as acetylcholine on our pancreas preparation, effects which were equally inhibited by atropine. The cholinergic receptors of the endocrine beta cell of the islet of Langerhans of the pancreas are therefore of the muscarinic type.

Key words: Beta cell, isolated pancreas, insulin secretion, acetylcholine, eserine, cholinergic receptors, muscarinic receptors, atropine, muscarine.
Numerous experimental findings support the assumption that the parasympathetic system plays a role in the regulation of the secretion of insulin.

The experiments of Clark in 1925 [1] and of $\mathrm{La}$ Barre in 1927 [11] had already suggested that stimulation of the vagus nerve provoked the secretion of insulin.

Some recent studies carried out using anesthetized dogs $[7,10,19]$ have shown that stimulation of the vagus nerve results in an increase of the secretion of insulin into the pancreatic venous blood.

Very recently Porte [20] by stimulating the distal end of the nerves which accompany the pancreaticoduodenal artery, obtained an acute release of insulin, an effect which was partially or totally blocked by the administration of atropine.

Along a parallel line with the above research, studies have been carried out in order to investigate the effects of the chemical mediator of the parasympathetic system, acetylcholine, on the secretion of insulin.

The first preparations employed were pieces of pancreas incubated "in vitro". Coore and Randle [4] found no effect of acetylcholine, in the presence of eserine and variable concentrations of glucose, on fragments of rabbit pancreas. On the other hand Malaisse et al. [16], using a large dose of acetylcholine $(8 \mu \mathrm{M})$ in the presence of eserine and glucose, detected a stimulatory effect on the secretion of insulin by fragments of rat pancreas incubated "in vitro"; this stimulatory effect was inhibited by atropine. The results obtained by Mayhew et al. [18] varied with the animal species considered. These authors, using rat pancreatic tissue incubated "in vitro", found no effect of either acetylcholine or carbachol in the presence of a glucose concentration of $1 \mathrm{~g} / \mathrm{l}$; but these two drugs inhibited the secretion produced by a concentration of glucose of $3 \mathrm{~g} / \mathrm{l}$.

In "in vivo" experiments on the anaesthetized dog, Kaneto et al. [9] obtained an increase in the plasma immunoreactive insulin in the pancreatic vein when methacholine and bethanechol were perfused in the pancreatic artery. This effect was blocked by atropine. In these experiments the effect of methacholine was much stronger than that of bethanechol.

The object of the work that we have carried out was to study the role played by acetylcholine and the cholinergic receptors of the beta cell of the islet of Langerhans in the secretion of insulin and to determine the pharmacological nature of these receptors. Our experiments were performed "in vitro" using isolated perfused rat pancreas; a preparation which permitted an accurate analysis of the intensity and the dynamics of insulin secretion.

It is our present purpose to report the results which we have obtained in their entirety, some of these having already appeared in preceding publications $[14,17]$.

\section{Material and Method}

A detailed description of the material and the perfusion technique of isolated rat pancreas has already been given $[12,15]$. 
We wish to underline the fact that the pancreas completely isolated from the surrounding organs, is perfused without recycling, through its arterial system, using a Krebs Ringer bicarbonate buffer. The glucose concentration of the perfusion fluid varies according to flowing out of the pancreas through the sectioned portal vein. In all our experiments, two samples taken at 30 and 45 min after the start of perfusion, served as controls of the functioning level of the organ before the administration of the drug to be studied.

Table 1. Effects of acetylcholine $(2.5 \mu M$ or $408 \mu \mathrm{g} / \mathrm{l})$ on the insulin output (ng/min) of 10 isolated perfused rat pancreas

\begin{tabular}{|c|c|c|c|c|c|c|c|c|c|c|}
\hline \multirow{4}{*}{$\begin{array}{l}\text { Rat } \\
\text { pancreas }\end{array}$} & \multicolumn{10}{|c|}{ Time in minutes } \\
\hline & 30 & 45 & 46 & 47 & 48 & 53 & 60 & 75 & 90 & 105 \\
\hline & & & \multicolumn{6}{|c|}{ Acetylcholine $2.5 \mu \mathrm{M} / 1$} & & \\
\hline & & & 1 & 2 & 3 & 8 & 15 & 30 & & \\
\hline 1 & 40 & 38.9 & 320 & 259 & 141 & 180 & 40.8 & 1.9 & 3.05 & 14.8 \\
\hline 2 & 24.1 & 31 & 297 & 231 & 130 & 155 & 83 & 15.8 & 7.3 & 27.6 \\
\hline 3 & 42.2 & 46.6 & 226 & 103 & 59.5 & 49.9 & 19.7 & 14.5 & 3.9 & 10.7 \\
\hline 4 & 24 & 24 & 155 & 103 & 55 & 40 & 29.7 & 36.3 & 5.5 & 33 \\
\hline 5 & 31.6 & 29 & 302 & 288 & 144 & 194 & 223 & 85.5 & 10.5 & 18.7 \\
\hline 6 & 45.3 & 68.4 & 425 & 245 & 144 & 227 & 29 & 0 & 0 & 0 \\
\hline 7 & 12.9 & 19.8 & 185 & 145 & 62.7 & 83 & 33.6 & 17.4 & 2.8 & 0 \\
\hline 8 & 16.6 & 30.6 & 300 & 232 & 106 & 75 & 105 & 30.9 & 13 & 15 \\
\hline 9 & 48.6 & 57.6 & 566 & 302 & 115 & 245 & 81.6 & 3.2 & 2.6 & 3.6 \\
\hline 10 & 33 & 32 & 222 & 162 & 65 & 96 & 84 & 6.7 & 6.7 & 17.4 \\
\hline M & 31.8 & 37.8 & 301 & 225 & 112 & 126 & 93 & 24 & 5.5 & 14 \\
\hline$\pm \mathrm{SEM}$ & 3.9 & 4.8 & 39 & 32 & 18 & 21 & 24 & 8 & 1.2 & 3.5 \\
\hline
\end{tabular}

Table 2. Effects of acetylcholine $(0.5 \mu M$ or $81.6 \mu g / l)$ on the insulin output (ng/min) of 18 isolated perfused rat pancreas.

\begin{tabular}{|c|c|c|c|c|c|c|c|c|c|c|}
\hline \multirow{4}{*}{$\begin{array}{l}\text { Rat } \\
\text { pancreas }\end{array}$} & \multicolumn{8}{|c|}{ Time in minutes } & & \multirow{2}{*}{$\frac{}{105}$} \\
\hline & 30 & 45 & 46 & 47 & 48 & 53 & 60 & 75 & 90 & \\
\hline & & & \multicolumn{6}{|c|}{ Acetylcholine $0.5 \mu \mathrm{M} / 1$} & & \\
\hline & & & 1 & 2 & 3 & 8 & 15 & 30 & & \\
\hline 1 & 20.8 & 25.0 & 82.7 & 45.8 & 31.2 & 19.2 & 9.7 & 8.1 & 8.1 & 8.1 \\
\hline 2 & 70.6 & 84.7 & 154.9 & 140.4 & 102.1 & 103.9 & 89.5 & 22.3 & 28.9 & 59.4 \\
\hline 3 & 46.0 & 48.3 & 155.0 & 111.0 & 59.0 & 71.5 & 73.5 & 6.8 & 12.0 & 19.2 \\
\hline 4 & 27.3 & 19.5 & 113.0 & 90.7 & 36.0 & 47.5 & 28.8 & 8.6 & 7.2 & 6.5 \\
\hline 5 & 16.1 & 12.1 & 72.7 & 44.5 & 17.2 & 10.5 & 6.3 & 7.0 & 4.8 & 5.7 \\
\hline 6 & 41.4 & 48.0 & 270.0 & 217.0 & 92.0 & 120.0 & 66.0 & 3.4 & 3.9 & 27.7 \\
\hline 7. & 27.6 & 22.0 & 193.0 & 155.0 & 58.6 & 7.0 & 0.0 & 0.0 & 0.0 & 0.0 \\
\hline 8 & 32.0 & 48.0 & 155.0 & 141.0 & 88.0 & 58.0 & 83.0 & 10.1 & 4.4 & 7.4 \\
\hline 9 & 31.0 & 42.0 & 270.0 & 193 & 76.5 & 142.0 & 169.0 & & 6.7 & 4.7 \\
\hline 10 & 83.0 & 71.0 & 109.0 & 138.0 & 45.0 & 20.0 & 20.0 & 53 & 94.0 & 200.0 \\
\hline 11 & 33.6 & 45. & 110.4 & 81.4 & 54.3 & 31.2 & 78.2 & 79.2 & 67.8 & 66.0 \\
\hline 12 & 32.4 & 35.1 & 152.9 & 94.7 & 37.8 & 15.0 & 43.4 & 83.3 & 73.0 & 57.0 \\
\hline 13 & 19.2 & 22.2 & 145.6 & 67.8 & 38.7 & 63.5 & 97.2 & 117.3 & 68.7 & 73.4 \\
\hline 14 & 39.0 & 42.4 & 281.8 & 188.9 & 65.4 & 142.6 & 140.9 & 174.1 & 143.9 & 165.4 \\
\hline 15 & 29.2 & 35.4 & 156.0 & 121.7 & 52.9 & 128.2 & 90.5 & 50.7 & 63.4 & 63.8 \\
\hline 16 & 59.3 & 80.0 & 393.0 & 331.0 & 145.0 & 221.0 & 243.0 & 299.0 & 171.0 & 209.0 \\
\hline 17 & 30.0 & 21. & 89. & 112 & 100.4 & 91.3 & 73.5 & 87.0 & 45.0 & 4.2 .5 \\
\hline 18 & 16.5 & 19.5 & 146.8 & 172.6 & 114.8 & 126.8 & 103.2 & 120.1 & 95.7 & 101.3 \\
\hline$\overline{\mathrm{M}}$ & 36.5 & 40.2 & 169.5 & 135.9 & 67.5 & 78.8 & & & & \\
\hline \pm SEM & 4.3 & 4.9 & 19.7 & 16.3 & 7.9 & 14.0 & * & $*$ & $*$ & * \\
\hline
\end{tabular}

* The mean values are not calculated owing to the very different behaviour of the pancreases. Some pancreases were strongly inhibited, some other pancreases remained stimulated

the experiments; the concentration most frequently used is $1.5 \mathrm{~g} / \mathrm{l}$, which slightly stimulates the secretion of insulin [13].

After a period of adaptation of $30 \mathrm{~min}$, the concentration of insulin is measured in the efferent fluid
Insulin was assayed by the radio-immunological method B of Hales and Randle [8]. The standard curve was made with rat insulin having a biological activity of $19 \mu \mathrm{U} / \mathrm{ng}$.

The drugs whose effects we wished to study were 
introduced in solution into the perfusion circuit in a continuous manner, generally for a period of thirty minutes.

Our results are given - either in tables - or in graphs. In this case the results are generally expressed as variations of the output rate of insulin; the variations are estimated in percentages as compared with the value measured at $45 \mathrm{~min}$, that is, immediately before the administration of the drug.

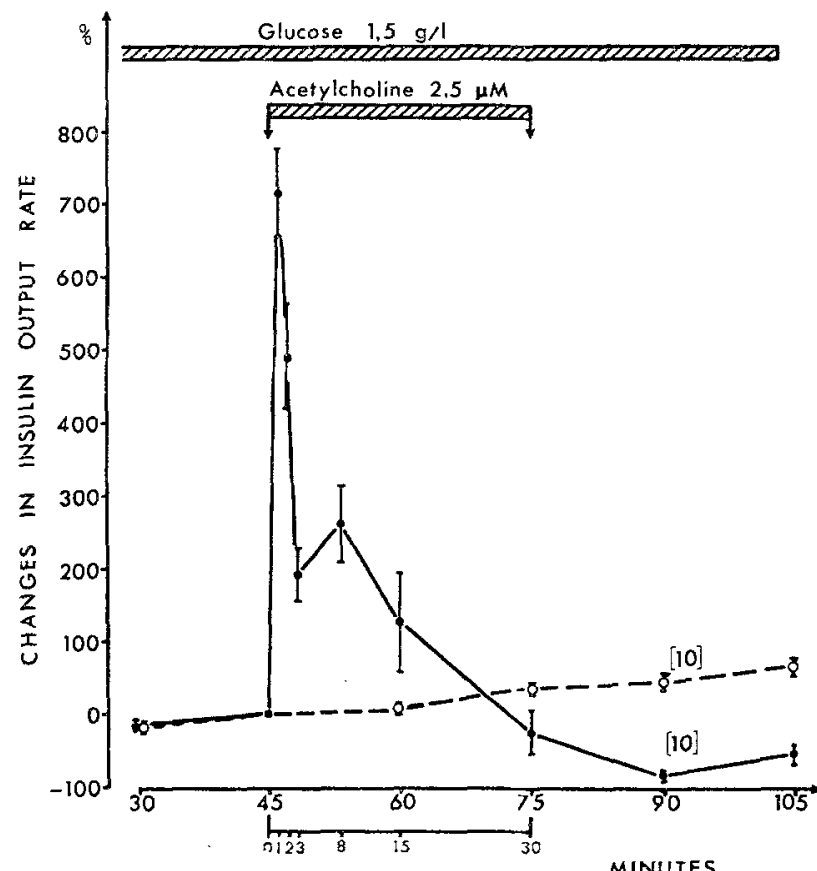

Fig. 1. Effects of acetylcholine $(2.5 \mu \mathrm{M}$ or $408 \mu \mathrm{g} / 1)$ on insulin secretion. The dotted line shows the secretion of the control. The number of pancreases in each group of experiments is indicated in parentheses. Each point represents the mean of the values and carries an indication of the standard error of the mean. The insulin output at time 45 minutes was as an average $37.8+4.8 \mathrm{ng} / \mathrm{min}$ for the treated and $44.7 \pm 3.6 \mathrm{ng} / \mathrm{min}$ for the controls

The times indicated start with the beginning of perfusion of the organ.

\section{Results}

\section{Effects of Acetylcholine on the Secretion of Insulin}

1. Effects of variable doses of acetylcholine on the kinetics of insulin secretion in presence of a glucose concentration of $1.5 \mathrm{~g} / \mathrm{l}$. a) The highest concentration of acetylcholine that we have used was $2.5 \mu \mathrm{M}(408 \mu \mathrm{g} / 1)$. The results in $\mathrm{ng} / \mathrm{min}$ obtained with this concentration are detailed in Table 1 . In figure 1 we have drawn the mean curve in per cent of basal. In all cases an immediate and very strong stimulation of the secretion of insulin was seen. At one minute this secretion was increased by more than $700 \%$ with reference to the control level. This constituted a peak since the ensuing secretion fell very rapidly and from the third minute the secretion was increased by less than about $200 \%$.

This first phase which was constant was followed by a second phase which could itself be subdivided into two periods: a first period lasting until the eight minute of infusion during which the secretion remained distinctly increased in all cases (Table 1), followed by a second period during which an inhibition of insulin secretion occurred. This inhibition was quite marked;

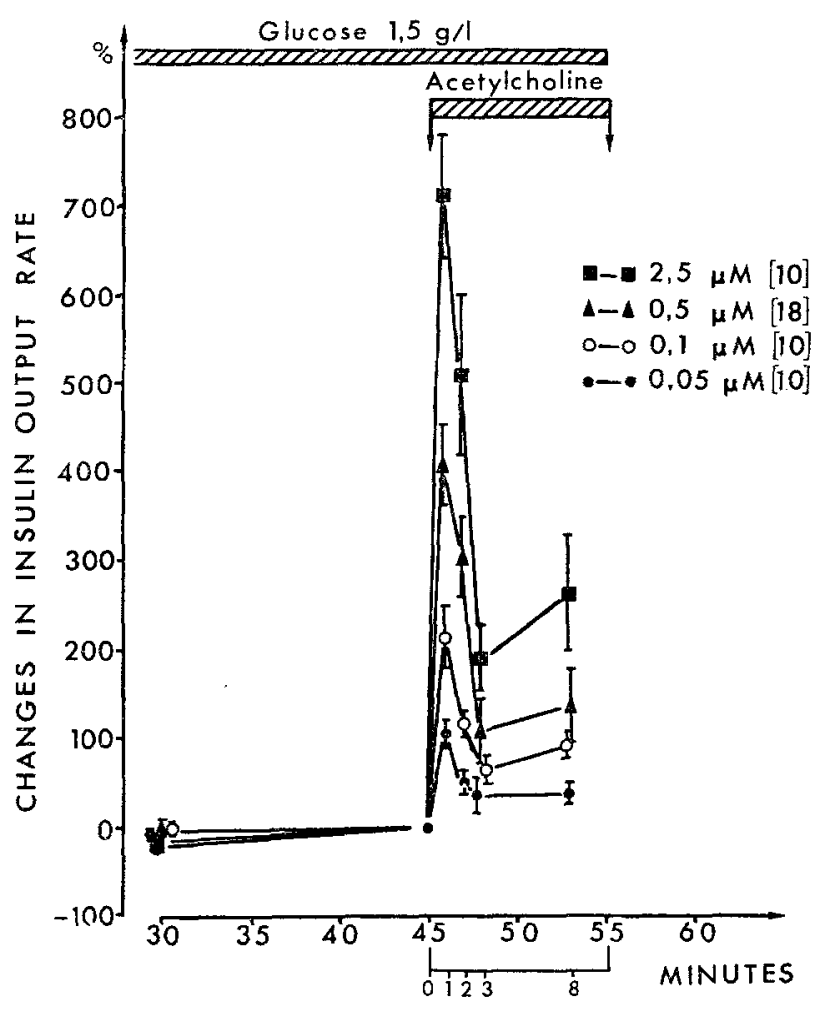

Fig. 2. The effects of increasing doses of acetylcholine $0.05 \mu \mathrm{M}, 0.1 \mu \mathrm{M}, 0.5 \mu \mathrm{M}$ and $2.5 \mu \mathrm{M}$ (or $8.16 \mu \mathrm{g} / \mathbf{l}, 16.3 \mu \mathrm{g} / \mathrm{l}$, $81.6 \mu \mathrm{g} / 1$ and $408 \mu \mathrm{g} / 1$ respectively) on insulin secretion. The number of panoreases in each group of experiments is indicated in parentheses. Each point represents the mean of the values and carries an indication of the standard error of the mean. The insulin output before the addition of acetylcholine was as an average for each of the groups $40.9 \pm 4.2 \mathrm{ng} / \mathrm{min}, 32.7 \pm 3 \mathrm{ng} / \mathrm{min}, 40.2 \pm 4.9$ $\mathrm{ng} / \mathrm{min}$ and $37.8 \pm 4.8 \mathrm{ng} / \mathrm{min}$ respectively

it most often began during the infusion of acetylcholine, (in either the $15 \mathrm{~min}$ or the $30 \mathrm{~min}$ sample) and lasted after the drug was discontinued until the end of the experiments, although in a declining manner in most cases.

b) At a concentration of acetylcholine five times lower than in the preceding trials $(0.5 \mu \mathrm{M}$ or $81.6 \mu \mathrm{g} / \mathrm{l})$ the initial peak of insulin secretion occurred quite as rapidly but was markedly lower (Table 2, Fig. 2).

The second phase then followed in which the pan. creases behaved inconsistently (Table 2). As with the dose of $2.5 \mu \mathrm{M}$, some of the pancreases (gathered in the top of Table 2) showed a strong and lasting inhibition 


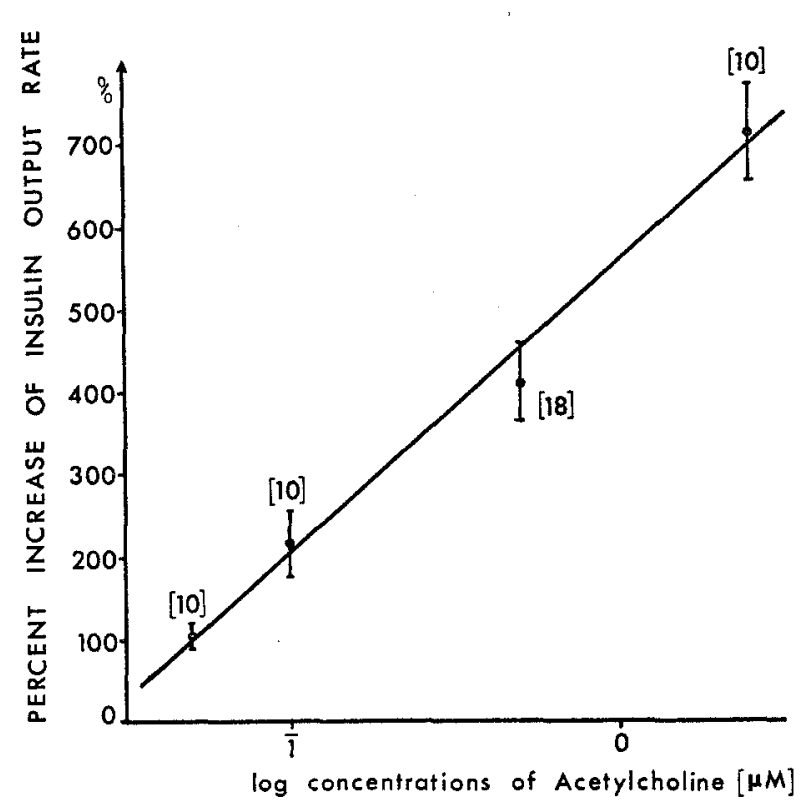

Fig. 3. Relationship between the percent increase of insulin output rate $(y)$ and the logarithm of acetylcholine concentration $(x)$. The calculated regression line has the following equation: $y=537+333 x$. Each point represents the mean of the values and carries an indication of the standard error of the mean. The number of pancreases is indicated in parentheses

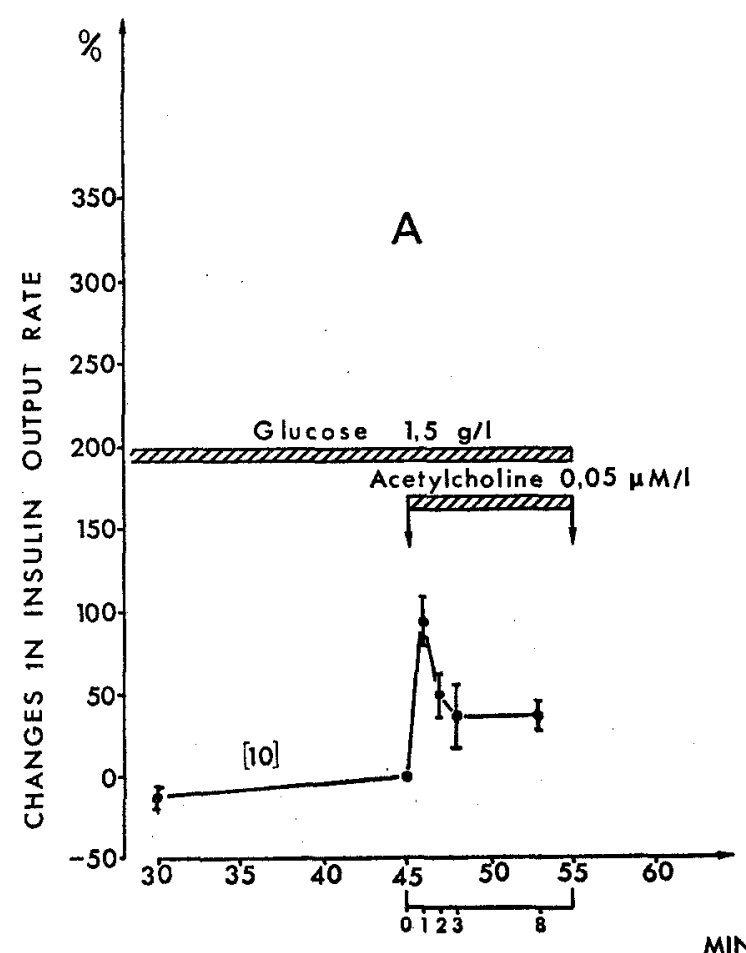

of their insulin secretion. This inhibition persisted even after the administration of the cholinergic substance was discontinued. However, other pancreases continued to be stimulated (particularly see pancreases $13,14,16$, 17,18 in Table 2). This stimulation was, however, less marked than that recorded at the time of the initial peak. The mean values in Table 2 are not indicated for the end of experiments owing to the variable behaviour of the pancreases (in either inhibition or stimulation).

c) In order to learn whether the insulin secretory effect which was constantly observed during the first minutes of acetylcholine infusion was dose related, we studied the action of decreasing concentrations of the drug: $2.5 \mu \mathrm{M}-0.5 \mu \mathrm{M}-0.1 \mu \mathrm{M}$ and $0.05 \mu \mathrm{M}$. Each curve in Fig. 2 represents the average results obtained from a group of pancreases perfused with these different concentrations of acetylcholine. It is clear that the peak of insulin secretion increased with the dose of drug administered.

We were more particularly interested in the peak of insulin secretion: that is the secretion of insulin obtained one minute after the beginning of the acetylcholine infusion at various concentrations. We have tried to construct a dose-effect curve for the value recorded at that time. Fig. 3 represents the relationship between the insulin output rate and the logarithm of the concentration. We note that this relationship does

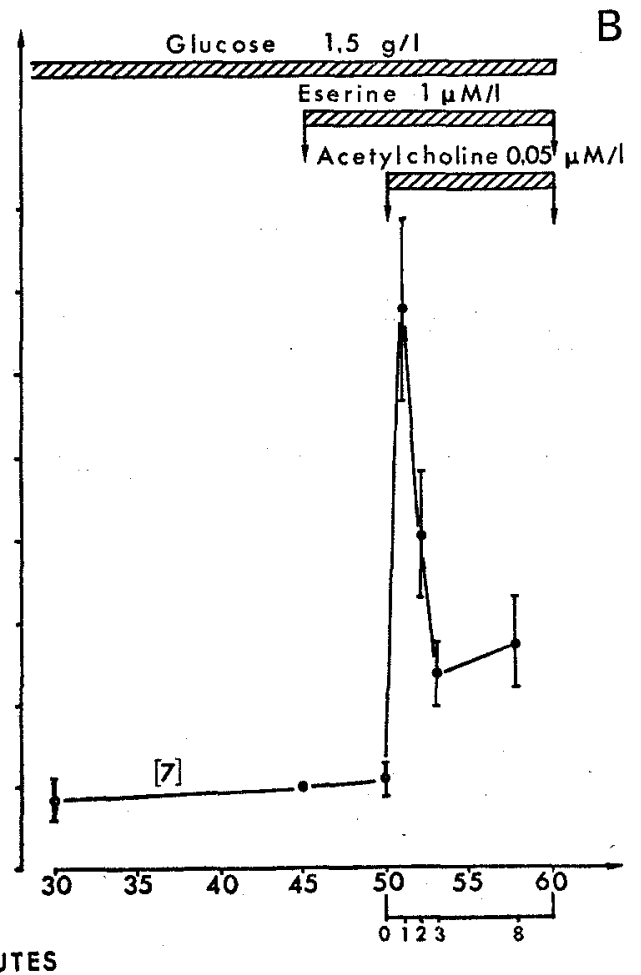

Fig. 4. This figure shows in part $A$ the effect of a concentration of acetylcholine of $0.05 \mu \mathrm{M}$ and in part B the effect of the same concentration in the presence of eserine $1 \mu \mathrm{M}(324 \mu \mathrm{g} / 1)$. Each point represents the mean of the values and carries an indication of the standard error of the mean. The number of pancreas is indicated in parentheses. The insulin secretion before the addition of the drugs was, on average $40.9 \mathrm{ng} / \mathrm{min}$ and $32 \mathrm{ng} / \mathrm{min}$ respectively 


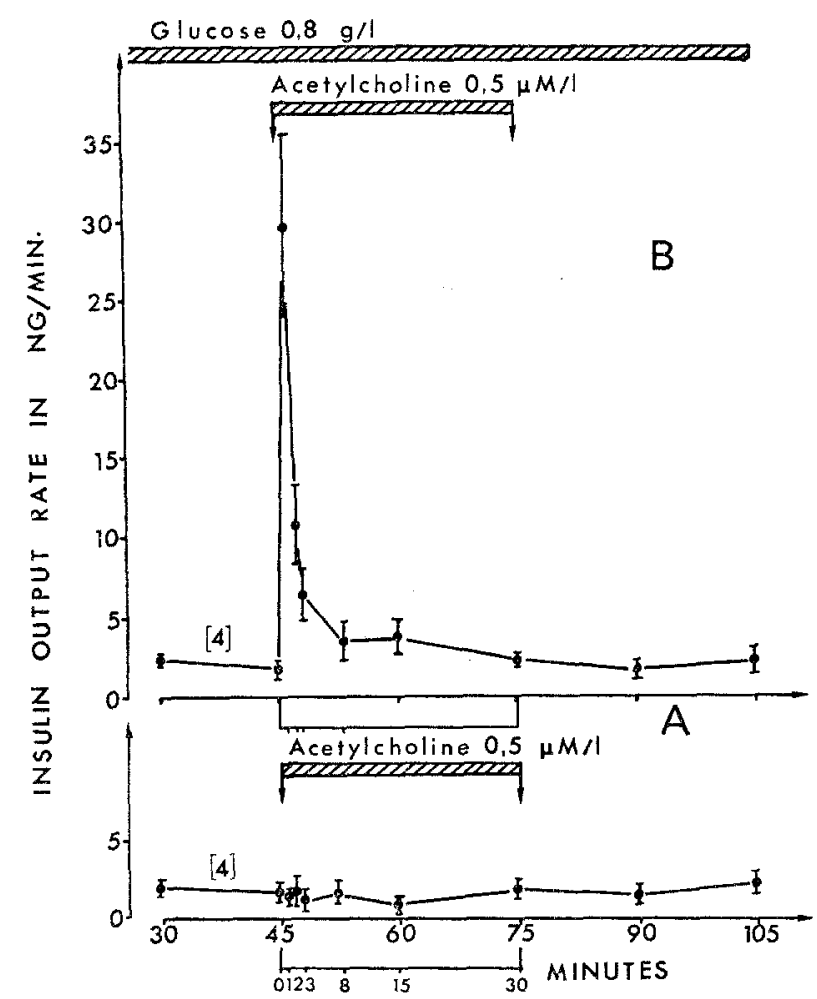

Fig. 5. Graph A: The effect of acetylcholine $(0.5 \mu \mathrm{M})$ on insulin secretion in the absence of glucose in the perfusion liquid. Graph B: The effect of acetylcholine $(0.5 \mu \mathrm{M})$ in the presence of a glucose concentration of $0.8 \mathrm{~g} / \mathrm{l}$ in the perfusion liquid. Each point represents the mean of the results and carries an indication of the standard error of the mean. The number of pancreas is indicated in parentheses
In order to do this, five minutes before infusing acetylcholine at a low dose of $0.05 \mu \mathrm{M}$, an infusion of eserine at a concentration of $1 \mu \mathrm{M}$ (or $324 \mu \mathrm{g} / \mathrm{l}$ ) was started, and this infusion was continued throughout the duration of acetylcholine infusion.

Our results are presented in Fig. 4. We note:

- that eserine by itself did not modify the secretion of insulin during the five minute period in which it was perfused alone: graph $B$.

- that eserine potentiated the action of acetylcholine: at the first minute of infusion, the increase in the output of insulin reached $+300 \%$, whereas it barely attained $+100 \%$ when the same concentration of acetylcholine was infused alone, (compare graphs $A$ and $B)$.

3. The role played by glucose in the effect of acetylcholine on the secretion of insulin. We were then concerned with a new problem: is glucose necessary to the action of acetylcholine on insulin secretion?

In four of our experiments the pancreas was perfused with a Krebs Ringer solution which contained no glucose. As we can see in Figure 5 graph A, an infusion of acetylcholine at a concentration of $0.5 \mu \mathrm{M}$ had no effect on the basal secretion of the pancreas: the values plotted on the ordinate represent the output of insulin in nanograms per minute. In the same figure (graph B), the results obtained in a series of experiments where the glucose concentration of the perfusion liquid was $0.80 \mathrm{~g} / \mathrm{l}$ are plotted. We notice that this concentration of glucose does not stimulate by itself the secretion of insulin; indeed, during the control period that preceded the infusion of acetylcholine, the secretion was practically the same as that obtained in

Table 3. Effects of acetylcholine in the presence of atropine on the insulin output (ng) min) of 6 isolated perfused rat pancreases

\begin{tabular}{|c|c|c|c|c|c|c|c|c|c|c|c|}
\hline \multirow{5}{*}{$\begin{array}{l}\text { Rat } \\
\text { pancreas }\end{array}$} & \multicolumn{11}{|c|}{ Time in minutes } \\
\hline & 30 & 45 & 46 & 48 & 51 & 52 & 53 & 58 & 65 & 80 & 95 \\
\hline & & & \multicolumn{9}{|c|}{ Atropine $0.3 \mu \mathrm{M}$} \\
\hline & & & & & \multicolumn{6}{|c|}{ Acetylcholine $0.5 \mu \mathrm{M}$} & \\
\hline & & & & & 1 & 2 & 3 & 8 & 15 & 30 & \\
\hline $\begin{array}{l}1 \\
2 \\
3 \\
4 \\
5 \\
6\end{array}$ & $\begin{array}{l}34.3 \\
16.1 \\
23.3 \\
28.7 \\
45.8 \\
48.7\end{array}$ & $\begin{array}{l}36.5 \\
16.1 \\
25.6 \\
36.6 \\
40.0 \\
53.6\end{array}$ & $\begin{array}{l}34.4 \\
16.1 \\
22.7 \\
36.9 \\
40.0 \\
53.5\end{array}$ & $\begin{array}{l}31.0 \\
20.2 \\
26.1 \\
41.7 \\
48.7 \\
35.9\end{array}$ & $\begin{array}{l}29.8 \\
15.6 \\
22.8 \\
37.5 \\
43.8 \\
51.4\end{array}$ & $\begin{array}{l}43.0 \\
16.5 \\
24.2 \\
44.5 \\
45.4 \\
57.0\end{array}$ & $\begin{array}{l}34.9 \\
18.9 \\
23.3 \\
41.3 \\
48.5 \\
56.5\end{array}$ & $\begin{array}{l}39.0 \\
14.9 \\
22.4 \\
39.3 \\
49.3 \\
56.0\end{array}$ & $\begin{array}{l}39.5 \\
16.3 \\
22.2 \\
42.1 \\
48.1 \\
40.8\end{array}$ & $\begin{array}{l}41.0 \\
14.4 \\
22.7 \\
41.1 \\
55.4 \\
48.6\end{array}$ & $\begin{array}{l}37.5 \\
20.3 \\
22.7 \\
41.5 \\
57.0 \\
60.0\end{array}$ \\
\hline $\begin{array}{l}\bar{M} \\
\pm \mathrm{SEM}\end{array}$ & $\begin{array}{r}32.8 \\
5.2\end{array}$ & $\begin{array}{r}34.9 \\
5.1\end{array}$ & $\begin{array}{r}33.9 \\
5.4\end{array}$ & $\begin{array}{r}33.9 \\
4.2\end{array}$ & $\begin{array}{r}33.4 \\
5.4\end{array}$ & $\begin{array}{r}38.4 \\
6.1\end{array}$ & $\begin{array}{r}37.2 \\
5.9\end{array}$ & $\begin{array}{r}36.8 \\
6.4\end{array}$ & $\begin{array}{r}34.8 \\
5.1\end{array}$ & $\begin{array}{r}37.2 \\
6.3\end{array}$ & $\begin{array}{r}39.8 \\
6.8\end{array}$ \\
\hline
\end{tabular}

not differ from a straight line within the range of the doses used $(0.05 \mu \mathrm{M}$ to $2.5 \mu \mathrm{M})$. The calculated regression line has the following equation: $y=537+333 x$.

2. The action of eserine on the effects of acetylcholine. We were interested to see whether eserine raised the effects of acetylcholine on the secretion of insulin. the absence of glucose. With this weak concentration of glucose, however, the response to the perfusion of acetylcholine was immediate, strong and brief. After this first phase of stimulation, the secretion of insulin progressively returned to the control value, without the appearance of a second phase. 
Having learned about the role of the cholinergic receptors of the insulin-secreting beta cell of the islets of Langerhans, it remained for us to determine the pharmacological nature of these receptors.

II. The Determination of the Muscarinic Character of the Cholinergic Receptors Involved in the Secretion of Insulin.

All of these experiments were carried out on several pancreases in which insulin secretion was slightly stimulated by a glucose concentration of $1.5 \mathrm{~g} / \mathrm{l}$.
As is shown in Table 3, atropine by itself, had practically no effect on the secretion of insulin during the five minute period in which it was perfused alone.

It totally counteracted the effects of acetylcholine, so that neither the peak insulin secretion of the first minutes, nor the second phase were observed.

2. The effect of muscarine on the secretion of insulin. Our experiments followed the same pattern as that used for the study of acetylcholine: after a period of 45 min of equilibration of the preparation, muscarine

Table 4. Effects of muscarine on the insulin output (ng/min) of 11 isolated perfused rat pancreas

\begin{tabular}{|c|c|c|c|c|c|c|c|c|c|c|}
\hline \multirow{4}{*}{$\begin{array}{l}\text { Rat } \\
\text { pancreas }\end{array}$} & \multicolumn{10}{|c|}{$\operatorname{Time}$ in minutes } \\
\hline & 30 & 45 & 46 & 47 & 48 & 53 & 60 & 75 & 90 & 105 \\
\hline & & & \multicolumn{6}{|c|}{ Muscarine $0.5 \mu \mathrm{M}$} & & \\
\hline & & & 1 & 2 & 3 & 8 & 15 & 30 & & \\
\hline 1 & 25.5 & 31.0 & 207.0 & 107.0 & 54.0 & 36.0 & 29.5 & 6.3 & 5.7 & 28.8 \\
\hline 2 & 29.4 & 36.0 & 154.8 & 105.6 & 64.2 & 41.1 & 21.1 & 4.6 & 16.5 & 16.5 \\
\hline 3 & 65.5 & 61.0 & 195.0 & 93.0 & 50.0 & 57.7 & 42.8 & 5.7 & 14.0 & 47.5 \\
\hline 4 & 31.0 & 34.0 & 94.0 & 54.0 & 25.0 & 18.0 & 23.0 & 2.5 & 3.2 & 15.0 \\
\hline 5 & 34.3 & 28.7 & 111.4 & 64.7 & 45.1 & 33.7 & 35.5 & 38.1 & 15.8 & 19.2 \\
\hline 6 & 44.5 & 49.5 & 108.5 & 74.9 & 53.1 & 88.6 & 71.6 & 73.5 & 87.6 & 105.0 \\
\hline 7 & 39.9 & 46.3 & 110.0 & 87.6 & 76.3 & 91.5 & 81.8 & 104.1 & 96.9 & 104.5 \\
\hline 8 & 30.4 & 25.0 & 109.8 & 16.7 & 16.5 & 40.8 & 46.4 & 52.6 & 40.0 & 61.9 \\
\hline 9 & 28.5 & 25.7 & 120.5 & 74.5 & 44.1 & 53.3 & 51.5 & 70.0 & 60.7 & 81.8 \\
\hline 10 & 13.0 & 14.0 & 55.0 & 34.0 & 21.0 & 26.0 & 17.0 & 27.0 & 21.0 & 17.0 \\
\hline 11 & 51.9 & 50.7 & 126.0 & 106.0 & 68.0 & 99.0 & 108.0 & 109.0 & 132.0 & 132.0 \\
\hline & 35.8 & 36.5 & 126.5 & 74.3 & 47.0 & 53.2 & & & & \\
\hline \pm SEM & 4.2 & 4.1 & 13.2 & 9.0 & 5.8 & 8.4 & * & * & * & * \\
\hline
\end{tabular}

* The mean values are not calculated owing to the different behaviour of the panereases. Some of them were strongly inhibited, some others remained rather stimulated

Table 5. Effects of muscarine in the presence of atropine on the insulin output (ng/min) of 5 isolated perfused rat pancreases

\begin{tabular}{|c|c|c|c|c|c|c|c|c|c|c|c|}
\hline \multirow{5}{*}{$\begin{array}{l}\text { Rat } \\
\text { pancreas }\end{array}$} & \multicolumn{11}{|c|}{ Time in minutes } \\
\hline & 30 & 45 & 46 & 48 & 51 & 52 & 53 & 58 & 65 & 80 & 95 \\
\hline & \multicolumn{11}{|c|}{ Atropine $0.3 \mu \mathrm{M}$} \\
\hline & \multicolumn{11}{|c|}{ Muscarine $0.5 \mu \mathrm{M}$} \\
\hline & & & & & $\overline{1}$ & 2 & 3 & 8 & 15 & 30 & \\
\hline 1 & 47.6 & 64.3 & 60.3 & 65.0 & 63.6 & 62.3 & 61.0 & 62.3 & 51.0 & 47.0 & $\overline{51.0}$ \\
\hline 2 & 48.0 & 54.7 & 55.6 & 73.3 & 52.0 & 54.3 & 55.6 & 58.0 & 48.6 & 42.3 & 60.3 \\
\hline 3 & 49.0 & 43.0 & 42.5 & $\tilde{5} 7.5$ & 45.5 & 48.0 & 46.5 & 50.5 & 56.0 & 57.0 & 77.5 \\
\hline 4 & 21.2 & 22.0 & 17.6 & 24.2 & 17.6 & 18.4 & 18.4 & 16.8 & 17.6 & 19.2 & 32.2 \\
\hline 5 & 30.8 & 26.4 & 19.8 & 22.0 . & 21.0 & 18.9 & 17.1 & 18.2 & 18.0 & 17.0 & 26.2 \\
\hline$\overline{\mathrm{M}}$ & 39.3 & 42.1 & 39.1 & 48.4 & 39.9 & $\overline{40.4}$ & 39.7 & 41.2 & 38.2 & 36.5 & $\overline{49.4}$ \\
\hline$\pm \mathrm{SEM}$ & 5.6 & 8.1 & 8.8 & 10.6 & 8.9 & 9.2 & 9.3 & 9.8 & 8.4 & 7.9 & 9.3 \\
\hline
\end{tabular}

1. Modifications of the effects of acetylcholine by atropine. In this group of experiments we have tried. to find out if atropine, a blocking agent of the "muscarinic" cholinergic receptors, modified the effects of acetylcholine. In order to do this, an infusion of atropine at a concentration of $0.3 \mu \mathrm{M}$ (or $96 \mu \mathrm{g} / \mathrm{l}$ ), was started $5 \mathrm{~min}$ before the infusion of acetylcholine $(0.5 \mu \mathrm{M})$ and was continued during the whole experiment, a period of $30 \mathrm{~min}$. was infoused at a dose of $0.5 \mu \mathrm{M}$ (or $87 \mu \mathrm{g} / \mathrm{l}$ ) for $30 \mathrm{~min}$. Our results are presented in Table 4.

The recorded effects are comparable to those of acetylcholine. The response to the infusion of muscarine was immediate: the secretion rate rose to an average of $+250 \%$ during the first minute of infusion and fell at once so that it returned at the third minute to a value close to the starting level.

At the eighth minute of infusion, the secretion was 
higher on the average than that of the control pancreases. Afterwards the evolution with time varied with the pancreas used: in some experiments a strong inhibition of the secretion of insulin was seen, in other experiments pancreases were stimulated.

3. Modification of the effects of muscarine by atropine administration. It was then appropriate to verify that atropine opposed the effects of muscarine. Five minutes before the infusion of muscarine, atropine was infused at a dose of $0.3 \mu \mathrm{M}$ and the two infusions were continued for $30 \mathrm{~min}$. The results are presented in Table 5. We can see that atropine unquestionably opposed the effects of muscarine.

\section{Discussion}

The isolated perfused rat pancreas preparation, in such manner as we employ it, is particularly well adapted for experiments designed to explore the dynamics of the secretion of insulin, since it allows precise measurement of slight variations in the secretion rate of insulin.

From the results we have obtained, one can see that when the isolated pancreas was infused with acetylcholine, the response, seen as stimulation, was immediate: the secretion of insulin rose to its maximum in the minute that followed the beginning of the infusion. This effect was dose-related within the limits of the drug concentrations that we have studied.

As far as these concentrations are concerned, they are markedly less than (and consequently closer to physiological concentrations) those used previously by other authors, on pieces of pancreas "in vitro" [16]. The concentrations of the cholinergic drug that we selected (included within the range of $5 \times 10^{-8} \mathrm{M}$ to $\left.2.5 \times 10^{-6} \mathrm{M}\right)$ are of the order which are generally employed for the study of the effects of acetylcholine on isolated organs other than the pancreas, such as isolated frog ventricle and isolated pieces of rat intestine $[2,3,21]$.

It must be emphasized that the presence of glucose in the perfusion liquid of the organ was essential for demonstrating the stimulatory effect of acetylcholine. On this point our results are in agreement with those of Malaisse et al. [16] who obtained no stimulatory effect of acetylcholine in the absence of glucose.

It is of interest to note that the perfusion of glucose at a concentration which has no stimulatory effect on the pancreas $(0.8 \mathrm{~g} / \mathrm{l})$, enabled the beta cell to respond to the infusion of acetylcholine. However the rise in insulin output obtained at this concentration was much less marked (on average, $30 \mathrm{ng}$ of insulin per minute) than that obtained in the presence of a higher glucose concentration $(1.5 \mathrm{~g} / \mathrm{l})$. Indeed with the latter concentration the insulin secretion attained on average a value of $170 \pm 20 \mathrm{ng} / \mathrm{min}$.
The concentration of glucose in the medium irrigating the beta cells appeared, therefore, to be an important factor for demonstrating the effects of acetylcholine.

The results obtained with the concentration of $2.5 \mu \mathrm{M}$, show that at this strong concentration acetylcholine produced, after the first phase of stimulation, a second phase, which manifested itself in all experiments (Table 1, Fig. 1) as a new stimulation of insulin secretion followed by a more or less rapidly appearing inhibition which however was constant and lasting. This was probably not due to exhaustion of the secretory ability of the beta cell, which would render it incapable of secreting insulin at a high rate, since this phenomenon of secondary inhibition did not take place if other substances that stimulated the secretion of insulin (such as the hypoglycemic sulfonamides) were used. One can then suggest that acetylcholine, when administered continuously at a sufficiently high concentration and for a long period of time modified the state of receptivity and/or response of the beta cell; this rendered the latter unable to respond to the stimulation provoked by glucase alone (at a concentration of $1.5 \mathrm{~g} / \mathrm{l})$.

If we consider the results obtained with an acetylcholine concentration five time weaker $(0.5 \mu \mathrm{M})$ (Table 2), we no longer systematically found, in the second phase, stimulation followed by inhibition, but, depending on the pancreas used, either stimulation followed by inhibition or a lasting stimulation. The variable behaviour of the various pancreases during this second phase is difficult to explain. It does not seem to be related to the magnitude of secretion during the control period. It can be seen that the inhibitory period induced by acetylcholine at $0.5 \mu \mathrm{M}$, when present, is only after several minutes of acetylcholine infusion, just as with the dose of $2.5 \mu \mathrm{M}$.

It is of importance to underline the point that atropine suppressed both the initial peak of insulin secretion as well as the second phase provoked by acetylcholine. It can be suggested that the two observed effects could be due to the action of acetylcholine on the cholinergic receptors of the beta cell.

The suppression of the action of acetylcholine by atropine, and the similar effect produced with muscarine as was obtained with acetylcholine are arguments in favor of the "muscarinic" nature of the cholinergic receptors of the beta cell of the islet of Langerhans of the rat pancreas.

Histochemical and autoradiographical methods $[5,6]$ show that cholinergic nerve endings are in close touch with the beta cells of the pancreatic islets. Our experiments thus provide evidence that the mediator acetylcholine, released at these endings, may play a role in the secretion of insulin. Quite probably modulating, as do adrenergic substances, the secretion of insulin. We must emphasize however, that this secretion is primarily regulated by the glucose concentration of the medium surrounding the islet beta cell. 


\section{References}

1. Clark, G.A.: The influence of the vagus on the islets of Langerhans. Part. I. Vagus hypoglycaemia. J. Physiol. 59, 466-471 (1925)

2. Clark, A.J.: The reaction between acetylcholine and muscle cells. J. Physiol. 61, 530-546 (1926)

3. Clark, A.J.: The reaction between acetylcholine and muscle cells. Part II. J. Physiol. 64, 123-143 (1927)

4. Coore, H.G., Randle, P.J.: Regulation of insulin secretion studied with pieces of rabbit pancreas incubated in vitro. Biochem. J. 93, 66-78 (1964)

5. Coupland, R.E.: The innervation of pancreas of the rat, cat and rabbit as revealed by the cholinesterase technique. J. Anat. 92, 143-149 (1958)

6. Esterhuizen, A.C., Spriggs, T.L.B., Lever, J.D.: Nature of islet-cell innervation in the cat pancreas. Diabetes 17, 33-36 (1968)

7. Frohman, L., Ezdinli, E., Javid, R.: Effect of vagotomy and vagal stimulation on insulin secretion. Diabetes 16, 443-448 (1967)

8. Hales, C.N., Randle, P.J.: Immuno-assay of insulin with insulin-antibody precipitate. Biochem. J. 88, $137-146(1963)$

9. Kaneto, A., Kajinuma, H., Kosaka, K., Nakao, K.: Stimulation of insulin secretion by parasympathomimetic agents. Endocrinology 83, 651-658 (1968)

10. Kaneto, A., Kosaka, K., Nakao, K.: Effects of stimulation of the vagus nerve on insulin secretion. Endocrinology 80, 530-536 (1967)

11. La Barre, J.: Sur l'augmentation de la teneur en insuline du sang veineux pancréatique après excitation du nerf vague. C.R. Soc. Biol. (Paris) 1927, 96, 193$196(1927)$

12. Loubatieres, A., Mariani, M.M., Ribes, G., De Malbose H., Chapal, J.: Etude expérimentale d'un nouveau sulfamide hypoglycémiant particulièrement actif, le HB 419 ou glibenclamide. I. Action betacytotrope et insulino-sécrétrice. Diabetologia 5, 1-10 (1969)

13. Loubatières, A., Mariani, M.M., Chapal, J.: Etude physiologique et pharmacologique de l'insulino- sécrétion. I. Effet du glucose et des sulfamides hypoglycémiants. J. de Pharmacologie 1, 7-24 (1970)

14. Loubatieres, A., Mariani, M.M., Chapal, J.: Etude sur le pancréas isolé et perfusé du rat, de l'action des récepteurs cholinergiques sur l'insulino-sécrétion. C.R. Soc. Biol. (Paris) 164, 2345-2349 (1970)

15. Loubatières, A., Alric, R., Mariani, M.M., Chapal, J.: Pancréas isolé et perfusé du rat. Fiche technique. J. de Pharmacologie 3, 103-108 (1972)

16. Malaisse, W., Malaisse-Lagae, F., Wright, P.H., Ashmore, J.: Effects of adrenergic and cholinergic agents upon insulin secretion in vitro. Endocrinology 80, 975-978 (1967)

17. Mariani, M.M., Loubatières, A., Chapal, J.: Récepteurs cholinergiques et insulino-sécrétion. Etude sur le pancréas isolé et perfusé du rat. 4ème Réunion de l'Association Francaise des Pharmacologistes. Paris 21-22 Novembre 1970. J. de Pharmacologie (Paris) 2, 98 (1971)

18. Mayhew, D.A., Goldberg, A.M., Wright, P.H.: The influence of cholinomimetics upon insulin secretion. Diabetes 17, (suppl. 1) 308-309 (1968)

19. Orsetti, A., Bourgeois, J.M., Belaiche, R., Macabies, J.: Effects de la stimulation du vague sur l'insulinémie chez le chien. C.R. Soc. Biol. (Paris) 164, 1573-1577 (1970)

20. Porte, D., Jr.: Neural regulation of insulin secretion. Diabetes 20, (suppl. 1) 340 (1971)

21. Van Rossum, J.M.: The relation between chemical structure and biological activity. J. Pharm. Pharmacol. 15, 285-316 (1963)

Professeur A. Loubatières

Laboratoire de Pharmacologie et de

Pharmacodynamie

Faculté de Médecine

Institut de Biologie

Boulevard Henri IV

F-34060 Montpellier

France 